Forthcoming, Review of Financial Studies

\title{
Can Housing Risk be Diversified? A Cautionary Tale from the Housing Boom and Bust
}

\author{
John Cotter ${ }^{1}$, Stuart Gabriel ${ }^{2}$ and Richard Roll ${ }^{3}$
}

\begin{abstract}
This study evaluates the effectiveness of geographic diversification in reducing housing investment risk. To characterize diversification potential, we estimate spatial correlation and integration among 401 US metropolitan housing markets. The 2000s boom brought a marked uptrend in housing market integration associated with eased residential lending standards and rapid growth in private mortgage securitization. As boom turned to bust, macro factors, including employment and income fundamentals, contributed importantly to the trending up in housing return integration. Portfolio simulations reveal substantially lower diversification potential and higher risk in the wake of increased market integration.
\end{abstract}

This draft: September 182014

Keywords: integration, housing risk diversification, housing returns

JEL Classification: G10, G11, G12, G14, R12, R21

1UCD School of Business, University College Dublin, Blackrock, Co. Dublin, Ireland. Email: john.cotter@ucd.ie and Research Fellow, Ziman Center for Real Estate, UCLA Anderson School of Management.

${ }^{2}$ Anderson School of Management, University of California, Los Angeles, 110 Westwood Plaza, Los Angeles, California 90095, stuart.gabriel@anderson.ucla.edu

${ }^{3}$ Caliornia Institute of Technology, Pasadena, CA 91125, rroll@caltech.edu.

The authors gratefully acknowledge research support from the UCLA Ziman Center for Real Estate. Cotter also acknowledges the support of Science Foundation Ireland under Grant Number 08/SRC/FM1389. The authors thank workshop participants at UCLA, the Red Rock Finance Conference, the 2013 EFA Annual Conference, the 2013 AREUEA International Meetings, the 2014 Israel Real Estate and Urban Economics Symposium, Dublin City University, Federal Reserve Bank of San Francisco, University College Dublin, Tel Aviv University, Xiamen University, and the Hebrew University of Jerusalem as well as David Aboody, Tom Conlon, Jason Chang, Tom Davidoff, John Duca, Fernando Ferreira, Liam Gallagher, Mark Garmaise, Mark Grinblatt, Francis Longstaff, Stijn Van Nieuwerburgh, Steve Oliner, Amiyatosh Purnanandam, Chester Spatt, Avanidhar Subrahmanyam and Robert Shiller for helpful comments. We are particularly grateful for the advice and suggestions from two anonymous referees and from Andrew Karolyi, the Executive Editor of this Journal. 


\section{Introduction}

Geographic diversification long has been fundamental in risk mitigation among investors and insurers of housing, mortgages, and mortgage-related derivatives. The housing governmentsponsored enterprises (GSEs), the Federal National Mortgage Association, (Fannie Mae) and the Federal Home Loan Mortgage Corporation, (Freddie Mac), now both in government conservatorship, diversified geographically in an effort to reduce the risk of investment in a single asset class (residential mortgages.) Similar logic was employed during the 2000s by prominent Wall Street firms, including Bear Stearns, Merrill Lynch, and Citigroup. More recently, geographic diversification has become central to the investment strategies of multi-family real estate investment trusts (REITs) and single-family housing investment funds. ${ }^{1}$

During the late-2000s meltdown, anecdotal evidence suggests that geographic diversification was far from effective. ${ }^{2}$ Diversification has limited power when returns are highly correlated. It seems likely that housing investors incurred substantial losses because of unforeseen and unprecedented contemporaneous price declines across geographically-distinct markets.

The effectiveness of geographic diversification also has important implications for private and government-backed insurers of residential mortgages. Substantial geographic correlation of credit losses, when coupled with sizable insurer guarantee liabilities and constrained access to credit markets, may render private mortgage insurance less viable. In such circumstances, policymakers may turn to alternative mechanisms, such as deeply-subordinated governmentbacked insurance on qualified mortgages, to assure liquidity and stability of the housing finance system.

\footnotetext{
${ }^{1}$ Freddie Mac's efforts to geographically diversify mortgage assets held in portfolio are discussed in their 2007 Annual Report, (p. 97). The 10-Ks of large residential REITs such as Mid-American Apartment Communities and Apartment Investments and Management Company similarly address the expected benefits of portfolio geographic diversification. Also, single-family housing hedge funds (e.g., Colony Capital) employ geographic diversification of single-family holdings as a strategy of risk mitigation.

${ }^{2}$ For example, sizable losses were recorded in the geographically diversified retained portfolios of the failed housing GSEs. As described by Michael Lewis (2010), the failure of diversified subprime mortgage-backed securities also figured importantly in the 2009 Bear Stearns, Merrill Lynch and Lehman insolvencies.
} 
Despite the prevalence of geographic diversification by investors and insurers of mortgages and housing, only a few studies have explicitly examined such strategies. Nadauld, Sherlund and Vorkink (2011) and Nadauld and Sherlund (2009), for example, examine loan collateral diversification in the context of sub-prime mortgage-backed securitization.

While those studies offer important insights, little is known about geographic diversification in housing in general and whether it changed over the recent boom and bust cycles. Indeed, while the finance literature has addressed issues of correlation and integration among global equity markets, little attention has been paid to the same issues among real estate markets. A few studies include assessment of integration among securitized real estate markets (see, for example, Liow (2010)) or between securitized real estate and equity markets (Lin and Lin, 2011). However, we are unaware of prior analysis of the magnitude or trend in metropolitan housing market integration, as evidenced by the relative exposure of housing returns to fluctuations in national economic, housing market, and housing finance factors. Further, little is known about the relative importance of macro and financial drivers of housing market integration and their variation over time or across geographies. Few studies have explicitly estimated temporal variation in risk associated with diversified housing investment portfolios. ${ }^{3}$

Measures of housing market integration and housing portfolio risk are important indicators of diversification benefits. Such indicators are relevant to the full spectrum of market participants, be they housing and housing derivative investors, homebuilders, and the like. They also provide policymakers with information about the temporal and geographic diffusion of macroeconomic shocks and national economic policy. Measures of housing market integration across metropolitan

\footnotetext{
${ }^{3}$ However, the literature includes related analyses of real estate investment trusts (REITs) using equity factors such as those developed by Chen, Roll and Ross (1986) and Fama and French (1993). Such studies include Chan, Hendershott and Sanders (1990) and Karolyi and Sanders (1998) who find, inter alia, that changes in expected inflation influence REIT returns. Explanations of REIT returns by the Fama-French (1993) factors are reported in Peterson and Hsieh (1997); whereas this approach has been expanded to include a momentum factor (Hung and Glascock (2010)) and the influence of liquidity (Cannon and Cole (2011).
} 
regions of the U.S. are vital as policymakers seek to re-structure the housing finance system and mitigate catastrophic risk associated with severe housing downturns.

Our study commences with an assessment of spatial correlation in housing returns. This includes an examination of contemporaneous and lagged return correlations among metropolitan statistical areas (MSAs.) High levels of MSA return correlation raise concerns for mortgage or housing investors seeking to diversify risk associated with investment in this asset class. We find large numbers of MSA pairs with contemporaneous and lagged housing return correlations at high levels of statistical significance. Large MSA housing return correlations appear to be especially pronounced in California. In that state, 98 percent of MSA paired returns are significantly correlated with a mean correlation level of about 77 percent.

Given evidence of high levels of spatial correlation in returns, we turn to an assessment of the integration of housing markets. Our measure of integration is based on the proportion of a MSAs housing market returns that can be explained by an identical set of national factors (see Pukthuanthong-Le and Roll (2009)). The level of integration is indicated by the magnitude of Rsquare, with higher values representing higher levels of integration. Two MSAs are viewed as perfectly integrated if the same national factors fully explain housing market returns in both areas. In that case, the R-square would be 1.0, implying no diversification potential between the MSAs.

We estimate housing market integration and drivers thereof over time and across markets. In so doing, we compute temporal variation in factor contribution to integration R-square as well as factor statistical and economic significance for quarterly time-series between 1992 and 2012. Also, we evaluate geographic variation in integration factor estimates. Results of the integration analysis are then employed to construct alternative metropolitan housing investment portfolios and to assess portfolio risks over the recent period of housing boom, bust, and beyond.

Findings reveal a pronounced trending up in US housing market integration over the period of boom and bust. Prior to the 2000s boom, integration held roughly steady at around 45 percent 
over the 1992 - 2004 period. However, starting in late 2004, average integration levels turned up and peaked at 67 percent in 2010. During 2011 and 2012, as the crisis abated, housing return integration trended back down to about 55 percent. Among California MSAs, integration is generally higher but the recent movements are similar, rising from about 63 percent in 2004 to around 90 percent late in the decade. By 2012, integration within California housing returns had declined to just over 80 percent. These recent movements in housing integration are robust to variations in MSA cohorts and estimation methods.

We are able to identify factors associated with the increased integration during the latter half of the 2000s. To do so, we compute the contribution to integration R-square associated with each factor. Innovations in mortgage finance, notably including securitization of non-conforming mortgages and ease of mortgage underwriting, were strongly associated with higher integration during the 2004 -2007 boom period. Estimated economic significance associated with those factors moved up substantially during the boom period. Also, while the t-statistics associated with those factor loadings tended to move together across US Census Bureau census divisions, they were most pronounced in California. These results coincide with arguments in the literature (see, for example, Favilukis, Ludvigson, and Van Nieuwerburgh (2013), Garriga, Manuelli, and Peralta-Alva, (2012), Duca, Muellbauer, and Murphy (2012) and Mian and Sufi (2009)) that the boom in house prices was fueled in no small measure by widespread easing in mortgage qualification and in the provision of non-conforming secondary market liquidity.

As boom turned to bust and the influence of mortgage liberalization waned, other macro factors, including employment and income fundamentals, contributed importantly to the ongoing trending up in housing return integration. Indeed, those factors were responsible for the majority of the increment in U.S. housing market integration during the post-boom period. Similarly, the estimated exposure to and economic significance of those macro fundamentals was heightened during the crisis period. More recently, and in the wake of the attenuation of the crisis, those same 
macro factors accounted for much of the downward adjustment in metro return integration. California MSAs tell a roughly similar story albeit with a markedly higher level of housing return integration.

Equal-weighted portfolios of the longest-available U.S. and California metropolitan housing cohorts show sharply rising levels of portfolio risk over the 2000s housing boom and bust. Changes in U.S. portfolio risk correlate strongly with the level of housing market integration. During the 2000s housing boom and bust, the simple correlation between the integration R-square and the standard deviation of portfolio returns is 0.96 ! During the crisis period, housing portfolio diversification provided only limited benefits in risk diversification. Indeed, the negative correlation between portfolio integration and diversification benefits averaged over -0.82 during the period of housing boom and bust. This combination seems to have left investors and insurers of housing credit risk rather exposed to the market downturn. Taken together, our findings offer a cautionary tale about geographic diversification as a mechanism to mitigate housing risk.

\section{MSA Return Correlations}

We study 401 metropolitan housing price indices from the U.S. Federal Housing Finance Agency (FHFA) that have been examined by others; (for example, see Clark and Coggin (2009); and Calomiris, Longhofer, and Miles (2008)). The FHFA series are weighted repeat-sale price indices associated with single-family homes. Home sales and refinancings included in the FHFA sample are associated with purchase mortgage loans conforming to the underwriting requirements of the housing GSEs-Fannie Mae and Freddie Mac. The restriction to GSEconforming mortgages may reduce housing price volatility. Nevertheless, the FHFA data comprise the most extensive cross-sectional and time-series of quality-adjusted house price indices publically available in the United States. ${ }^{4}$ There were only 214 MSAs in the database at the beginning of the 
sample, (1985Q1) but the number increased rapidly, reaching 347 at the end of 1989 and the current number, 401, in the second quarter of 2005.

There is a general uptrend from 1985 through the first half of the 2000s in the national average of the metropolitan area house price indexes. But, as is well-known, the latter half of the 2000s saw a marked boom and then a sharp bust pattern. The California pattern is similar though the up- and down-swings are much more pronounced. Figure A-1 in Internet Appendix A plots the unweighted average index over the entire US and the corresponding average index for 29 California MSAs.

Housing returns for each MSA are computed quarterly from first differences of the logarithm of index levels ${ }^{5}$. Return correlations are then computed between all MSA return pairs (total sample $\mathrm{N}=80,200$ distinct pairs; i.e., 401(400)/2). The mean contemporaneous correlation of all MSAs return pairs is 0.29 , with a considerable cross coefficient standard deviation of 0.19 . However, assuming independence across the correlations, the t-statistic associated with the mean of 0.29 is over 428 , indicating a highly significant average correlation among MSA returns. Further evidence of strong correlation is the fact that 52,806 pairs have t-statistics for individual pairwise correlations exceeding 2.0, with a mean correlation of $0.394 ; 35,460$ pairs have t-statistics

${ }^{4}$ The HPI is a broad measure of the movement of single-family house prices. The HPI is a weighted, repeatsales index that measures average price changes in repeat sales or refinancings on the same properties. This information is obtained by reviewing repeat mortgage transactions on single-family properties whose mortgages have been purchased or securitized by Fannie Mae or Freddie Mac since the inception of the index in January 1975. The HPI is updated each quarter as additional mortgages are purchased or securitized by Fannie Mae and Freddie Mac. The new mortgage acquisitions are used to identify repeat transactions for the most recent quarter and for each quarter since the first quarter of 1975. In contrast to the value-weighted Case-Shiller US house price index, FHFA's index includes data from a comprehensive set of metropolitan housing markets in the U.S. and weights price trends equally for all properties. For a full discussion of the FHFA house price index, see Calhoun (1996) and for a critique of the series in the context of alternative house price series see Nagaraja, Browny, and Wachter (2010).

${ }^{5}$ In principle, it would be desirable to model house prices at higher frequencies. Unfortunately, monthly quality-adjusted house price indices are available from FHFA only for Census Divisions ( $\mathrm{N}=18$ ) and only for a much shorter time frame. 
exceeding 3.0, with mean correlation, 0.462. More details about the distribution of inter-MSA correlations are reported in Table A-1 of Internet Appendix A.

Table 1 reports contemporaneous and leading MSA house return correlation coefficients computed over the entire sample, 1985-2012, and averaged by US Census Bureau census divisions. Given its more pronounced boom and bust, California is reported separately from other states in the Pacific census division. (The remaining Pacific census division states are Oregon, Washington, Alaska, and Hawaii.6) The left panel of Table 1 reveals that house return correlations vary substantially across US census divisions. Over the entire 27 years of available data, the first eight census divisions had housing returns mean correlations in the range of roughly 0.2 to 0.4 , with not more than 40 percent highly significant. This would imply adequate potential for geographic diversification. But New England and California offer distinctly less potential. California in particular would be problematic because 98 percent of its MSA pairs are significantly contemporaneously correlated and the mean correlation is about 0.77 .

As reported in the right panel of table 1, average one-quarter lagged plus leading correlations are low in the first eight census divisions, with fewer than 30 percent being statistically significant. In marked contrast, MSAs in New England and California are characterized by relatively high percentages of significant and elevated lagged correlations. California is again the outlier; over 90 percent of its MSAs record significant lagged and leading return correlations, with a mean correlation of 0.67 .7

\footnotetext{
${ }^{6}$ This partition of the Pacific division is maintained in all division-level exhibits in the paper.

${ }^{7}$ In unreported work, we examined MSA extreme or "jump" movements in housing returns. Jumps were computed using the Lee and Mykland (2008) measure. Results indicate substantially higher levels of extreme house returns during the late 2000s housing boom and bust, especially in California. Further, contemporaneous and lead correlations in housing extreme returns were highly pronounced among California MSAs.
} 


\section{Integration}

Substantial research has studied the integration of international equity markets (for a comprehensive review of this topic and related research see Gagnon and Karolyi (2006)). The dynamics of equity market integration has been investigated by Harvey (1991), Chan, Karolyi, and Stulz (1992), Engle and Susmel (1993), Bekaert and Harvey (1995), Longin and Solnik (1995), and Errunza, Hogan, and Hung (2007). Papers have tended to vary in geographic focus, as some address integration in the European community (see, for example, Hardouvelis, Malliaropoulos, and Priestley (2006), and Schotman and Zalewska (2006)), whereas others investigate emerging markets (see, for example, Bekaert and Harvey (1995), Chambet and Gibson (2008), Bekaert, Harvey, Lundblad and Siegel (2011)). Some employ the US as a benchmark market (Ammer and Mei (1995) and Karolyi and Stulz (1996)).

There is also considerable variation in methods. For instance, Carrieri, Errunza and Hogan (2007) use GARCH-in-mean to assess correlation in returns and volatility among markets, while Longin and Solnik (1995) use cointegration. As in our paper, Bekaert, Harvey and Ng (2005) use multiple economic fundamental factors. Integration is often described in terms of cross-country correlations in stock returns (for an early study see King and Wadhwani (1990)); however, correlation may be a misleading measure.

When multiple factors drive returns, markets may be imperfectly correlated but perfectly integrated. As shown by Pukthuanthong and Roll (2009), while perfect integration implies that identical global factors fully explain index returns across countries, some countries may differ in their sensitivities to those factors and accordingly not exhibit perfect correlation. ${ }^{8}$

\footnotetext{
${ }^{8}$ For a straightforward intuitive example of such, consider an energy-exporting country such as Saudi Arabia and an energy-importing country such as Hong Kong. Both countries might be positively associated with global factors such as consumer goods or financial services. Moreover, both countries could be fully integrated in the global economy. Yet the simple correlation between their stock market returns could be relatively small, or even negative, because higher energy price increase Saudi equity values and decrease Hong Kong equity values. As a consequence, the extent to which the multi-factors drive returns is a better indication of likely diversification benefits than a correlation measure.
} 
Pukthuanthong-Le and Roll (2009) provide a simple intuitive measure of financial market integration based on the proportion of a country's returns that can be explained by an identical set of global factors. This measure of integration implicitly regards country-specific residual variance in a factor model as an indicator of imperfect integration. ${ }^{9}$ Clearly, to the extent global factors explain only a small proportion of variance in a country's returns, the country would be viewed as less integrated (see, for example, Stulz (1981) and Errunza and Losq (1985)). ${ }^{10}$ In contrast, markets would be viewed as highly integrated to the extent their returns are well explained.

We extend this idea to US housing markets. Those markets should be regarded as highly integrated if identical US national factors explain a large portion of the variance in MSA-specific housing returns. Hence to measure US housing market integration, we employ the explained variance (r-square) from a regression of metropolitan housing returns on an identical set of national economic, financial, and housing market fundamentals.

\section{a. Model Data and Specification}

For each MSA in the sample, the housing return is regressed on a common set of national economic, housing, and financial market factors. These factors were previously employed in explaining housing returns by Himmelberg, Mayer and Sinai (2005), Glaeser, Gyourko and Saks (2006), Ortalo-Magne, and Rady (2006), Hua, and Craig. (2011), Gerdesmeier, Lenarcic and Roffia (2012) and Gyourko, Mayer and Sinai (2006).

Also included are factors representing mortgage underwriting and secondary market liquidity. These are suggested by many researchers and analysts who argue that the 2000s housing boom was abetted, if not fueled entirely, by a marked easing of mortgage qualification and near-

\footnotetext{
${ }^{9}$ In contrast, in the presence of multiple national factors, the simple correlation between MSA housing return indexes could be a flawed measure of integration unless those MSAs have identical exposure to the national factors, e.g., unless the estimated coefficient vectors are exactly proportional across MSAs.

${ }^{10}$ According to this definition, a country is perfectly integrated if the country-specific variance is zero after controlling for global factors. In the case of two perfectly integrated countries, market indexes would have zero residual variance. See Pukthuanthong and Roll (2009) for discussion and details.
} 
ubiquitous expansion in non-conforming loan securitization; (for example, see Favilukis, Ludvigson, and Van Nieuwerburgh (2013), Garriga, Manuelli, and Peralta-Alva, (2012), Duca, Muellbauer, and Murphy (2012) and Mian and Sufi (2009)). As boom turned to bust and liquidity waned, more stringent underwriting, including income and employment information,, became important for mortgage qualification and housing demand.

The explanatory factors include average borrower loan-to-value ratio (LTV), private residential mortgage-backed securities issuance (PRIVMBS), payroll employment (PAYEMS), equity markets (S\&P500), industrial production (INDPRO), PPI materials prices, (PPITM) personal income (INCOME), consumer sentiment (UMCSENT), single-family building permits (PERMIT1), and the Federal Funds rate (FEDFUNDS). All explanatory factor data are quarterly over 1985:Q1 - 2012:Q4. Further details are provided by Tables A-2 and A-3 in Internet Appendix A, which provide summary statistics and their respective correlations. Data for the factors are obtained from the Federal Reserve Bank of St. Louis FRED (Federal Reserve Economic Data) with the exception of the S\&P500 (Datastream), private MBS issuance (Federal Reserve Flow of Funds Accounts), LTV (FHFA), and personal income (US Bureau of Economic Analysis). ${ }^{11}$ The log first differences of all these variables were used in the factor model to explain housing returns.

Integration is measured by the R-square from the multi-factor model fit to a sequence of 30quarter moving windows for each MSA.12 There are 112 quarters available for the MSA and factor data beginning in 1985:Q1, so the first 30-quarter window spans 1985:Q1 through 1992:Q2. There are 83 30-quarter windows in all.

The equal-weighted R-square averaged over all available MSAs portrays the mean level of integration during the period spanned by each moving window. Changes in this average MSA R-

\footnotetext{
${ }^{11}$ We looked at factors both individually and in combination in their explanation of housing returns. That assessment was based on their relative contribution to the level of integration over time. Also, we tested for the effects of other factors, such as changes in the industrial organization of the real estate industry, as reflected in a Herfindahl index of homebuilder concentration. That term yielded only limited increment to regression explanatory power and was not quantitatively important to the trend in integration R-square displayed in Figure 1.

${ }^{12}$ Note there is no evidence of serial correlation in the regressions residuals.
} 
square from one window to the next track the evolution of integration on average for the U.S. The contribution of individual common factors to integration is quantified by their separate influences on the average R-square.

\section{b. Return Regressions on National Factors}

The US housing market has become more integrated since 2004, (Figure 1.) Figure 1 plots the average R-square over the 1992:Q2 - 2012:Q4 period for the national and California samples. On the national level, integration held roughly steady around 45 percent over the $1992-2004$ period. The boom and bust period in housing was characterized by a strong uptrend in MSA market integration to roughly 66 percent by end of decade. More recently, integration levels eased back to about 55 percent in late 2012 .

In California, metropolitan housing market integration trended up from around 63 percent in 2004 to a 90 percent at decade's end. While California integration eased to about 80 percent by 2012, it remained highly integrated.

To control for the possibility that newly introduced MSAs differ in their degree of integration (smaller cities were added later), we examined the trends in R-square for three separate cohorts. A similar procedure is followed by Jorion and Goetzmann (1999) and Pukthuanthong-Le and Roll (2009) to deal with the timing of inclusion of individual stocks in market indices. The cohorts include cities that were in the database continually from 1985:Q1 through 2012:Q4 (cohort 1), cities added from 1989:Q1 through 2012:Q4 (cohort 2), and those added from 1992:Q3 through 2012:Q4 (cohort 3). ${ }^{13}$ Internet Appendix A plots the resulting trends. Panel A of Figure A-2 shows that the cohorts all display a similar pattern, a marked upward trend in housing market integration over the 2000s boom and bust followed by some fall off in recent years.

We also assess the robustness of housing integration results to window length. While longer windows provide additional degrees of freedom, they also result in shorter integration time-

\footnotetext{
${ }^{13}$ The 3 cohorts are chosen such that the final integration series yields values starting in 2000:Q1.
} 
series. We checked this with window lengths of 30, 40, and 50 quarters. Regardless of window length average integration hovers in the 30 to 40 percent range over the first half of the 2000s but displays a marked uptrend in integration over the latter half of the decade. Also, while the 30 and 40 quarter moving window series show a decline in average US housing market integration in 2011 and 2012, integration levels remain well above of those for the pre-boom years of the 2000 s. $^{14}$

MSA housing market cross-sectional and time-series summary statistics for the full US sample and for California are reported in Table 2. The table reports mean quarterly housing returns, standard deviations of returns (sigma), mean first and last R-square measures for each of the integration time-series regressions, the change in R-square over the full sample and over the 2000-2012 period, and the associated R-square time trend t-statistics (R-squares for each MSA are fit to a simple linear time trend for all available quarters). For the entire U.S., summary crosssectional statistics are presented for quintiles, minimum, maximum, mean and standard deviations of all return and integration characteristics. ${ }^{15}$ To save space, fewer cross-MSA statistics are reported in Panel B for California.

First, for the entire U.S., note from the first two columns of Panel A that risks and returns associated with housing have been substantial. The average quarterly return for all MSA housing markets is $0.794 \%$ with an average standard deviation of $2.088 \%$. Moreover, there is substantial cross-MSA variation; for example, mean housing return varies from a minimum $0.165 \%$ to a sample maximum of $1.412 \%$.

The mean final period R-square of the integration model is .556, revealing the importance of national influences on MSA housing returns. On average, R-squares increase about 11 percent from the beginning to end of sample. In some areas, however, national economic and housing market fundamentals fail to explain much of the variation in MSA-specific housing returns (e.g., the

\footnotetext{
${ }^{14}$ Panel B of Figure A-2 in Internet Appendix A plots average house price integration for the US national sample across window lengths of 30,40 and 50 quarters.

${ }^{15}$ Integration results for each of the 401 MSAs are available from the authors upon request.
} 
minimum 2000 R-square is 0.089). At the other extreme, those same fundamentals explain 92.5 percent of MSA-specific housing returns at the start of the millennium. There is also substantial variation in the change in R-square across the sample with a standard deviation of 0.235 .

Panel B of Table 2 reports much of the same information for the 29 California MSAs included in our dataset. In comparison to the full national sample of 401 MSAs, California housing markets are characterized by elevated returns, return volatility, and housing market integration. For instance, the mean final period R-square for the California MSAs is 81.9 percent, well in excess of the 55.9 percent average over the nation as a whole. This implies that national factors are more important for housing returns in California than in other regions. However, within California there is substantial temporal and cross-MSA variation in integration.

The average integration R-square in California moved up over the 2000-2012 period by 15.1 percent and the integration trend was highly statistically significant. Elevated integration levels in the latter half of the 2000s may have limited investor ability to diversify housing risk geographically across housing markets.

\section{c. Integration Drivers}

In this section, we seek to identify the drivers of the significant upward movement in housing market integration estimated for the latter half of the 2000s. To do so, we compute the contribution to integration R-square of each factor in the model. We also assess factor statistical and economic significance (using a bootstrap procedure to be described below) for all factors and all moving windows.

Further, we investigate variation in factor significance across U.S. census divisions. Our objective is to assess the role of economic fundamentals relative to innovations in mortgage finance, particularly those associated with mortgage underwriting and securitization, in their respective contributions to integration trends. As already mentioned, lengthy discussions by policymakers, 
academics, and journalists have pointed to the salience of such influences in the recent house price boom and bust.

As a caveat before beginning, however, we would be the first to admit that the factors associated here with housing returns are not necessarily comprehensive, exclusive or even exogenous. It is clearly possible that some unknown omitted variables caused co-movement in house prices and mortgage underwriting standards. The explanatory factors may indeed be proxying for other underlying influences that are thus far unidentified. Thus, we hesitate to claim that the estimated coefficients of the factors indicate marginal causative impacts. However, bootstrap results (below), show that estimated factor betas are mostly well-estimated. Finally, even if the factors are mere proxies, the integration measure (R-square) should still be meaningful; substituting the true underlying variables, if any, for the factor proxies would likely produce a similar level of measured integration. Moreover, direct portfolio risk assessment (as in section IV below) is immune to this issue and provides very similar inferences.

As shown in figure 1, US and California housing market integration trended up throughout the period of housing boom and bust. The average US (California) integration R-square moved 38 (65) percent in 2004 to about 53 (85) percent in early 2008. As boom turned to bust, integration continued to increase, reaching about 66 (90) percent in 2009. Subsequently, as the crisis abated, US housing market integration began to ease down.

To examine the contribution of each factor to integration R-square, we start with a singlefactor model and then incrementally add an additional factor and re-estimate the model. We continue this procedure until all factors are included in the model. In figure 2, we plot the incremental R-square associated with each regression. For example, the plot labelled LTV shows the R-square from a single factor model that has only the loan to value ratio (LTV) as the explanatory variable. We then augment the model to include private mortgage-backed securities issuance (PRIVMBS); the plot labelled PRIVMBS shows the R-square from this two-factor model 
that includes LTV and PRIVMBS. Note that the difference in R-square between the two-factor and single-factor models shows the incremental explanatory power associated with the PRIVMBS factor. The final model, labelled FEDFUNDs (for the Federal Funds interest rate), includes all 10 factors up to and including FEDFUNDs. This last model is identical to the housing integration trend shown in Figure 1. Results of this exercise are robust to the order in which the factors are entered into the model.

As shown in Figure 2, the uptrend in R-square during the 2004 to early 2008 boom period is explained by increased power of several factors notably including private mortgage securitizations (PRIVMBS) and the loan-to-value ratio (LTV). This corroborates findings cited already (see, for example, Favilukis, Ludvigson, Van Nieuwerburgh (2013), Garriga, Manuelli, and Peralta-Alva, (2012) Duca, Muellbauer and Murphy (2012) and Mian and Sufi (2009)) suggesting that the boom in house prices was fueled in no small measure by ease of mortgage underwriting and availability of non-conforming secondary market liquidity. As further shown in figure 2, subsequent trending up in integration during the bust period reflects the increased importance of economic fundamentals, particularly personal income (INCOME) which was responsible for virtually all of the increment to U.S. housing market integration during the crisis period. Income also accounts for much of the downward adjustment in integration as the crisis waned. This is true for California as well (Panel B of Figure 2) but for that region LTV played a more influential and time-varying role.

To help estimate factor statistical and economic significance, we use a bootstrap procedure. Five hundred bootstrap re-samplings are conducted for each 30-quarter period, the first ending in Quarter 2, 1992 and the last ending in Quarter 4, 2012. During each 30-quarter interval, there are between 214 and 401 MSAs available with complete data. The number of MSAs increases over time as more metropolitan areas enter the data base. ${ }^{16}$ The bootstrap procedure re-samples both MSAs

\footnotetext{
${ }^{16}$ The maximum number of MSAs prevails after Quarter 3 of 2008 (i.e., for the last 50 samples) and there are at least 300 MSAs after Quarter 3 of 1994 (i.e., only the first nine samples have fewer than 300 MSAs.)
} 
and quarters within each sample. ${ }^{17}$ Since both the MSAs and time periods are chosen randomly in each replication, the 500 regression results are independent. Hence, the cross-replication standard deviation of each coefficient, divided by the square root of the number of MSAs present in that sample period, is an unbiased estimate of the standard error of the mean coefficient estimate.

Estimates from the bootstrap are very closely related to the regression coefficients estimated from the original data. For example, the bootstrap t-values for factor loadings, (bootstrap means divided by bootstrap standard errors,) are highly correlated with the t-values obtained from the data; these correlations range from a low of .915 to a high of .987 across the ten explanatory factors and nine of ten have correlations above .95 .

The bootstrapped factor betas also provide insight regarding drivers of MSA housing return integration. As suggested above, the boom period was characterized by eased mortgage underwriting and enhanced secondary market non-conforming liquidity provision, both of which allowed substantial numbers of previously unqualified households to obtain mortgage credit.

For both housing finance factors, PRIVMBS and LTV, we see a strong relationship between the pattern in levels of integration and factor significance. In the early part of the sample, these factors have relatively low statistical power as the level of integration remained relatively steady. In contrast, during the rise and subsequent fall of integration during the boom and bust, both PRIVMBS and LTV's statistical influence increased substantially along with the trend in integration levels. From 2004-2008, the t-statistics for factor loadings of PRIVMBS start increasing and become

\footnotetext{
${ }^{17}$ For example, suppose that there are 400 MSAs with full data in a given sample period. First, a random number between 1 and 400 is chosen. Suppose this number is 175 , which fixes the 30 quarterly returns for the MSA that is ranked 175 alphabetically during that sample period. Next, a random number is drawn between 1 and 30 . This determines a calendar quarter for the 175th MSA's real estate return and the concurrent factor movements; these values become regression observation \#1. Then, another random number between 1 and 30 is drawn (with replacement) to determine a second calendar quarter that becomes regression observation \#2. This is repeated a total of 30 times, with replacement. Then, a regression is estimated with the 30 randomly chosen real estate returns (for the 175th MSA) as dependent variable and the randomly chosen (but contemporaneous) factor movements as explanatory variables. Next, a second MSA is chosen randomly with replacement and the process repeated to get a second set of regression estimates. This was repeated 500 times. Since each sample periods overlaps by 29 quarters with the next one, period-by-period sample averages not independent, though a case could be made that the bootstrap results ARE independent, despite the overlap in the original data, because the resampling is randomized.
} 
in general highly significant. As boom turns to bust and the levels of integration begin to fall, there is a change in direction, and eventually, sign of the PRIVMBS factor loading. A similar pattern occurs for the LTV factor, although its statistical influence remains positive in the more recent period.

As we saw in Figure 2, among economic fundamentals, income contributes importantly to the level of integration. When the level of integration started rising from 2004, income became the dominant factor. The bootstrap verifies that income factor loadings are positive and significant during the upturn in integration trends while they turn significantly negative as integration declines. Analogously, the other economic fundamental factor identified as contributing substantially to integration, payroll employment, (PAYEMS), has a similar pattern increasing to significance during the boom period and subsequently declining.

Another question of interest is whether the impact of factors is universal across MSAs. To examine this issue, we exploit the geographical disaggregation used earlier into census divisions. Statistical influence for explanatory factors varies to some extent across census divisions but the time pattern of their influence is similar. Plots of bootstrap t-statistics for the most important variables are provided by census division in Internet Appendix A, Figure A-3.

The corresponding bootstrapped factor economic significance is displayed in figure 3 . Each factor was first normalized to mean zero and unit variance during each replication of the bootstrap regressions. Hence, the economic impact can also be read on the same vertical scale along with statistical significance. The economic impact is in units of percent per quarter of metro housing returns so that the coefficients represent the impact of a one standard deviation change in the factor on the quarterly percent return. The minimum and maximum of the vertical scale are, respectively, $-4 \%$ per quarter and $+3 \%$ per quarter and is sufficient so that all variables can be judged relative to each other. 
Figure 3 reveals that the estimated economic impact of PRIVMBS moves up sharply over the boom period. Its coefficient is precisely estimated and of substantial magnitude, suggesting that by 2008, a 1 standard deviation change in log private MBS issuance was associated, on average, with more than a 2 percent increase in quarterly housing returns. The economic significance of mortgage underwriting, defined as log conforming loan-to-value ratio (LTV) for all borrowers, also trended up some between 2004 - 2007. The coefficient also is precisely estimated, suggesting in 2007 that a 1 standard deviation change in log conforming LTV was associated, on average, with about a 1 percent increase in quarterly housing returns. Indeed, results here are consistent with findings of other recent studies in suggesting that mortgage underwriting and liquidity, the latter in the form of enhanced provision of non-conforming secondary market finance, were important to the house price run-up of the boom period. As further indicated by Figure 3, the economic significance of both the LTV and private mortgage securitizations factors sharply declined in recent years.

As suggested above, as housing boom turned bust and in the wake of the waning of mortgage supply factors, economic fundamentals took on more significance in explanation of average metropolitan housing returns. Indeed, the ongoing rise in return integration during the 2008 - 2010 owed largely to the elevated importance of the income factor. Indeed, MSA housing return integration continued to trend up even as house price indices were moving in the opposite direction. As shown in figure 3, the economic significance of payroll employment trended up markedly during the latter half of the 2000s. By decade's end, a 1 standard deviation in log percent change in payroll employment was associated with a 2 percent increase in quarterly MSA average housing returns. Log personal income had an even more sizable effect. Further, the estimated coefficient on the income term turned sharply negative during the final years of the decade, reflecting ongoing downward adjustments in house prices even as economy-wide income fundamentals began to improve. 


\section{MSA Return Integration and Portfolio Risk Diversification}

Finally, we assess the relations among portfolio diversification, integration, and risk for U.S. metropolitan housing markets. As noted in the introduction, geographic diversification long has been a key strategy for risk mitigation by investors and insurers of housing, mortgages, and mortgage-related derivatives. For example, Freddie Mac, the Federal Home Loan Mortgage Corporation, sought to geographically diversify its single-family loan portfolio to reduce credit risks. ${ }^{18}$ During the 2000s boom years, Wall Street investment banks employed similar diversification strategies in assembly of mortgage-backed securities and related derivatives. More recently, newly-formed single-family housing investment funds and large, multifamily real estate investment trusts also have employed geographic diversification to mitigate portfolio risk. ${ }^{19,} 20$

To capture diversified risks of housing, we examine equal-weighted portfolios of the longest available U.S. and California housing cohorts (1992:Q2 - 2012:Q4). Housing return volatility (standard deviation) is computed for each MSA using a 30-quarter moving window. Diversification is measured by the difference between average MSA volatility and portfolio volatility.

In Figure 4, panels A and B, we provide evidence of integration and diversification for the U.S. and California metropolitan areas. Particularly evident are the strong opposite movements during the housing boom years of the 2000s. ${ }^{21}$ For the U.S. as a whole, average integration moved up from about 40 percent at the start of decade to approximately 65 percent by the decade's end. Over that

\footnotetext{
${ }^{18}$ See Freddie Mac Annual Report, 2007 (p. 97).

${ }^{19}$ Colony Capital, for example, has sought to reduce risk via geographic diversification of the holdings of its singlefamily housing hedge fund.

${ }^{20}$ See, for example, explicit statements on the intended benefits of geographic diversification that appear in the 10Ks of large residential REITs including Mid-America Apartment Communities and Apartment Investment and Management Company (AIV).

${ }^{21}$ In unreported work, we find that the relation between correlated jumps and diversification is similar; increased incidence of correlated jumps results in lower diversification possibilities. So when markets experience large and negative correlated price movements, the ability to diversify away this risk is reduced substantially, and at precisely the time when this mitigating effect is most desirable.
} 
decade, risk mitigation associated with housing portfolio diversification fell by more than one-half. As reported in table 3 panel A, the simple correlation coefficient between integration (R-square) and diversification was -.966 during the decade of the 2000s. But it was negative and large in absolute value during other periods as well, periods when neither measure moved as much.

When housing regions are well integrated, geographic diversification benefits are meagre. In more recent years and in the wake of attenuation of the crisis, diversification opportunities improved a bit while the simple correlation between integration and diversification became less pronounced..$^{22}$

A qualitatively similar pattern is observed for California MSAs in panel B of figure 3e, but the levels are different because this region is more integrated with national influences. During the 2002s, California's average housing return integration increase from 67 to 90 percent while its diversification fell precipitously and ended at a paltry 5 percent of the maximum..$^{23}$

As reported table 3, California's housing market integration and portfolio diversification exhibit strong negative correlation, thereby mimicking the country as a whole. The simple correlation coefficient between those series was -.862 for the full $1992-2012$ timeframe and -.836 for the decade of the 2000s although it fell to some extent during the boom and bust.

In sum, analysis of simulated investment portfolios indicates sizable upward adjustment to measured risk in the context of the pronounced increase in portfolio integration over the 2000s housing boom and bust. The increases in portfolio risk reflect sharp declines in opportunities for investment diversification. While integration slowed in 2011 and 2012, our findings still suggest substantial limitations to geographic diversification as a strategy for portfolio risk mitigation.

\footnotetext{
${ }^{22}$ The equal-weighted portfolio results for the US are robust to the exclusion of California MSAs.

${ }^{23}$ The theoretical maximum would be the elimination of all individual risk at the portfolio level.
} 


\section{Conclusion}

This paper evaluates the effectiveness of geographic diversification for risk mitigation among investors and insurers of housing. Using data from 401 US MSAs, it computes spatial correlation and return integration among US housing markets over the last three decades. To provide insight about the drivers of housing integration, it estimates national factor contributions to integration along with their statistical and economic significance.

Our national multi-factor model reveals a marked trending up in housing market integration during the 2000s. Among California MSAs, integration reached 90 percent of the possible maximum. Portfolio simulations reveal reduced diversification potential and higher risk in the wake of increased market integration.

Factors associated with the mid-2000s housing market boom and trending up in integration include eased residential lending standards and a growth in private mortgage securitizations. As boom turned to bust, macro factors including employment and income fundamentals contributed largely to the ongoing rise in housing return integration. The degree of national factor significance largely moved in tandem across US regions.

Our findings shed new light on the poor performance of geographically-disparate housing and residential MBS investments during the late 2000s. The results suggest that losses to private and government-backed mortgage insurers could possibly reach unsustainable levels in a severe housing downturn. While various proposals are now being debated, a possible future structure of the housing finance system, as discussed by Hancock and Passmore (2011) and Scharfstein and Sunderam (2011), might be to retain some form of mortgage insurance in the public sector, but deeply subordinate taxpayer exposure by allowing only the assumption of catastrophic risk on qualified mortgages. Our findings underscore the importance of efforts to develop appropriate mechanisms to assure the liquidity and stability of the housing finance system during periods of severe housing downturn. 
Taken together, our findings offer a cautionary tale about portfolio geographic diversification as a mechanism to mitigate housing risk. Indeed, during the late-2000s period of housing market boom and bust, local fundamentals became less important to MSA-specific returns. In such circumstances, investors and insurers of housing and mortgages must be able to withstand high levels of systemic risk. 


\section{References}

Ammer, J. and Mei., J., 1996, Measuring International Economic Linkages with Stock Market Data, Journal of Finance 51, 1743-1763.

Bekaert, G., and Harvey, C., 1995, Time-Varying World Market Integration, Journal of Finance 50, 403-444.

Bekaert, G., Harvey, C., and Ng, A., Ng, 2005, Market Integration and Contagion, Journal of Business 78, 39-69.

Bekaert, G., Harvey, C., Lundblad, C., and Siegel, S., 2011, What Segments Equity Markets? Review of Financial Studies, 24, 3847-3890.

Calhoun, C. A., 1996, OFHEO House Price Indexes: HPI Technical Description, Office of Federal Housing Enterprise Oversight, March.

Calomiris, C. W.; Longhofer, S. D.; and Miles, W., 2008, The Foreclosure-House Price Nexus: Lessons from the 2007-2008 Housing Turmoil, NBER Working Papers: 14294, National Bureau of Economic Research.

Cannon, S., \& Cole, R., 2011. Changes in REIT liquidity 1988-2007: Evidence from Daily Data, Journal of Real Estate Finance and Economics, 43, 258-280.

Carrieri, F., Errunza, V., and Hogan, K., 2007, Characterizing World Market Integration Through Time, Journal of Financial and Quantitative Analysis, 42, 915-940.

Chambet, A., and Gibson, R., 2008, Financial Integration, Economic Instability, and Trade Structure in Emerging Markets, Journal of International Money and Finance 27, 654-675.

Chan, K. C., Patric H. Hendershott and Anthony B. Sanders, 1990, Risk and Return on Real Estate: Evidence from Equity REITs, Real Estate Economics, 18, 431-452.

Chan, K. C., G. A. Karolyi, and R. M. Stulz, 1992, Global Financial Markets and the Risk Premium on U.S. Equity, Journal of Financial Economics 32, 137-167.

Chen, Nai-Fu, Richard. Roll and Stephen. A. Ross., 1986, Economic Forces and the Stock Market: Testing the APT and Alternative Asset Pricing Theories, Journal of Business, 59, 383-403.

Clark, S. P., and Coggin, T. D., 2009, Trends, Cycles and Convergence in U.S. Regional House Prices, Journal of Real Estate Finance and Economics, 39, 264-83. 
Duca, J. V., Muellbauer, J. and Murphy, A., 2012, Shifting Credit Standards and the Boom and Bust in U.S. House Prices: Time Series Evidence from the Past Three Decades, Oxford University Working Paper.

Engle, R. and R. Susmel, 1993, Common Volatility in International Equity Markets, Journal of Business and Economic Statistics 11, 167-176.

Errunza, V., and Losq, E., 1985, International asset pricing under mild segmentation: Theory and test. Journal of Finance 40, 105-124.

Errunza, V., K. Hogan, and M.-W. Hung, 2007, Characterizing World Market Integration through Time, Journal of Financial and Quantitative Analysis, 42, 915-940.

Fama, Eugene F., and Kenneth R. French, 1993, Common Risk Factors in the Returns on Stocks and Bonds, Journal of Financial Economics, 33, 3-56.

Favilukis, J., Ludvigson, S. C., and Van Nieuwerburgh, S., 2013, The Macroeconomic Effects of Housing Wealth, Housing Finance, and Limited Risk-Sharing in General Equilibrium, New York University Working Paper.

Gagnon, L., and Karolyi, A., 2006 Price and Volatility Transmissions Across Borders, New York University Salomon Center Monograph Series Financial Markets, Institutions \& Instruments, Volume 15, Number 3, August.

Garriga, C., Manuelli, R.E. and Peralta-Alva. 2012, A Model of Price Swings in the Housing Market. Federal Reserve Bank of St. Louis Working Paper Series.

Gerdesmeier, D., Lenarcic, A. and Roffia, B., 2012, An Alternative Method for Identifying Booms and Busts in the Euro Area Housing Market, European Central Bank, Working Paper Series: 1493.

Glaeser, E.L., Gyourko, J. and Saks, R.E., 2006, Urban Growth and Housing Supply, Journal of Economic Geography, 6, 71-89.

Gyourko, J., C. Mayer and Sinai, T., 2006, Superstar Cities, National Bureau of Economic Researhc Working Paper12355.

Hancock, Diana, and Wayne Passmore, 2011. Catastrophic Mortgage Insurance and the Reform of Fannie Mae and Freddie Mac, in Baily, Martin N. ed., The Future of Housing Finance: Restructuring the U.S. Residential Mortgage Market. Washington, DC: Brookings Institution Press.

Hardouvelis, G., Malliaropoulos, D., and Priestley, R., 2006, EMU and European Stock Market Integrations Journal of Business 79, 369-392. 
Harvey, C., 1991, The World Price of Covariance Risk, Journal of Finance 46, 111-159.

Himmelberg, C., C. Mayer and T. Sinai (2005), Assessing High House Prices: Bubbles, Fundamentals and Misperceptions, Journal of Economic Perspectives, 89, 323-336.

Hua, C. and Craig, R. S. 2011, Determinants of Property Prices in Hong Kong SAR: Implications for Policy, International Monetary Fund, IMF Working Papers: 11/277.

Hung, Kathy., and Glascock, John, 2010, Volatilities and Momentum Returns in Real Estate Investment Trusts. Journal of Real Estate Finance and Economics 41: 126-149.

Jorion, P. and W. Goetzmann, 1999, Global Stock Markets in the Twentieth Century, Journal of Finance 54, 953-980.

Karolyi, G. A. and Stulz, R. M., 1996, Why do Markets Move Together? An Investigation of U.S.Japan Stock Return Comovements, Journal of Finance 51,951-986.

Karolyi, G. A., and Sanders, A. B., 1998, The Variation of Economic Risk Premiums in Real Estate Returns, Journal of Real Estate Finance and Economics, 17, 245-262.

King, M. A., and S. Wadhwani, 1990, Transmission of Volatility between Stock Markets, Review of Financial Studies, 3, 5-33.

Lee, S., and Mykland, P., 2008, Jumps in Financial Markets: A New Nonparametric Test and Jump Dynamics, Review of Financial Studies 21, 2535-2563.

Lewis, Michael, 2010, The Big Short: Inside the Doomsday Machine, W.W. Norton \& Co., New York, ISBN-0-393-07223-1.

Lin, T. C., and Lin, Z-H., 2011, Integration between Securitized Real Estate and Stock Markets: A Global Perspective, Pacific-Basin Finance Journal, 19, 571-85

Liow, Kim Hiang, 2010, Are Stock and Real Estate Markets Integrated? An Empirical Study of Six Asian Economies, Journal of Real Estate Portfolio Management 16 (3), 249-65.

Longin, F., Solnik, B., 1995, Is the Correlation in International Equity Returns Constant: 19601990? Journal of International Money and Finance 14, 3-26.

Mian, A. and Sufi, A., 2009, The Consequences of Mortgage Credit Expansion: Evidence from the US Mortgage Default Crisis, Quarterly Journal of Economics, 124, 1449-96.

Nadauld, T. D., and Sherlund, S. M., 2009, The Role of the Securitization Process in the Expansion of Subprime Credit, Fisher College of Business Working Paper Series, The Ohio State University. 
Nadauld, T. D., Sherlund, S. M. and Vorkink, K., 2011, Correlated Collateral, Working Paper. Available at http://dx.doi.org/10.2139/ssrn.1573042.

Nagaraja, C. H., Browny, L. and Wachter, S. M., 2010, House Price Index Methodology, Working Paper, University of Pennsylvania.

Ortalo-Magne, F. and S. Rady, 2006, Housing Market Dynamics, on the Contributions of Income Shocks and Credit Constraints, Review of Economic Studies, 73, 459-485.

Peterson, James D. and Cheng-Ho Hsieh, 1997. Do Common Risk Factors in the Returns on Stocks and Bonds Explain Returns on REITs?, Real Estate Economics, 25, 321-345.

Pukthuanthong-Le, K., and Roll, R., 2009 Global Market Integration: An Alternative Measure and Its Application, Journal of Financial Economics, 94, 214-232.

Scharfstein, David S., and Adi Sunderam,, 2011, The Economics of Housing Finance Reform, In The Future of Housing Finance, edited by Martin Neil Baily, Brookings Institution Press.

Schotman, P., and Zalewska, A., 2006, Non-synchronous trading and testing for market integration in Central European emerging markets, Journal of Empirical Finance 13, 462-494.

Sinai, T., 2011, House Price Moments in Boom-Bust Cycles, Working Paper, Wharton School, University of Pennsylvania.

Stulz, R., 1981, On the effects of barriers to international investment. Journal of Finance 36, 923934. 


\section{Figure 1}

\section{Housing Return Integration Trends}

Average R-squares for US MSAs and California MSAs

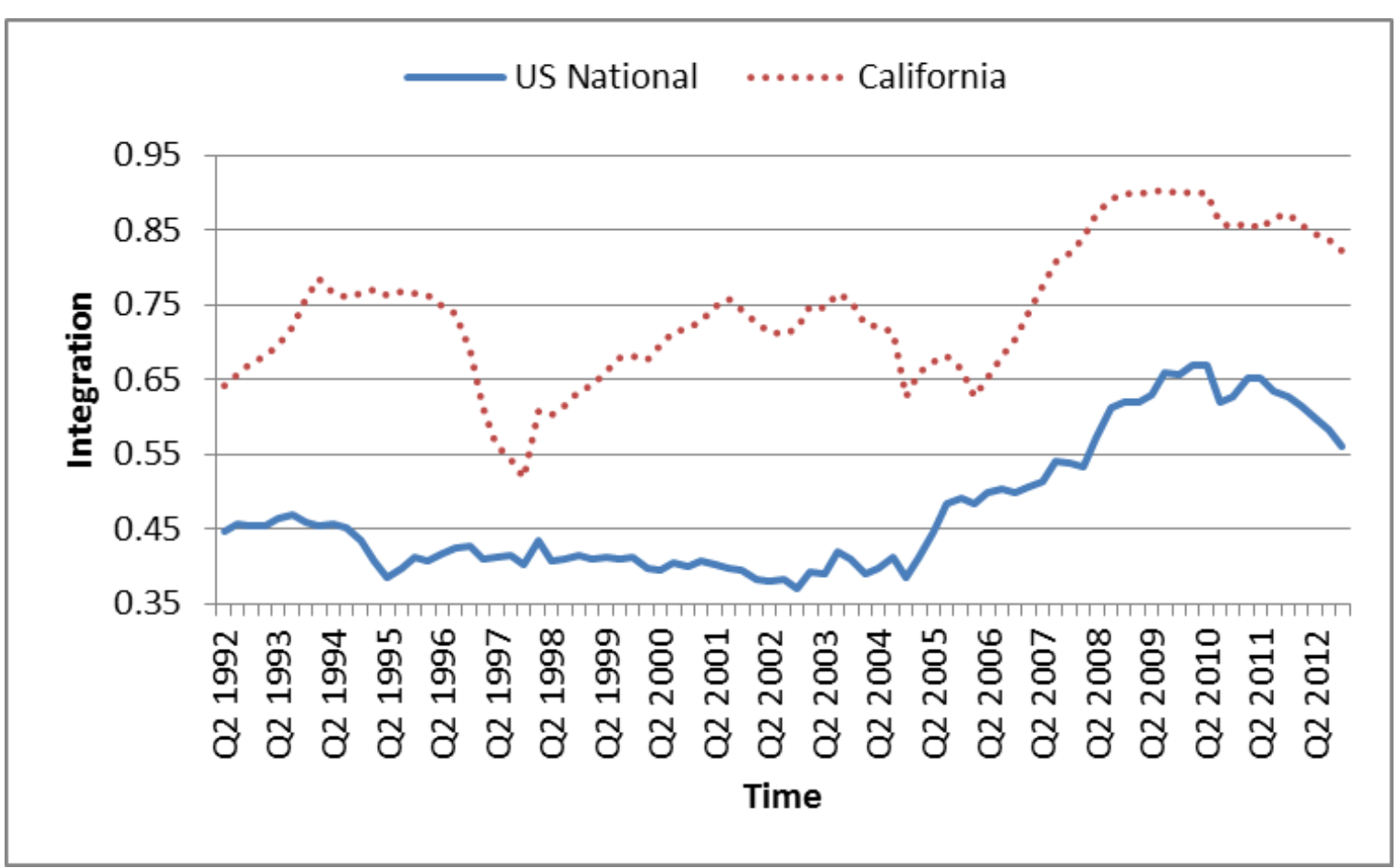

Notes: The level of integration is measured by the average R-squares from the multi-factor housing returns model fitted over a sequence of 30-quarter moving windows, 1992:Q2 - 2012:Q4 for 401 US MSAs and for 29 California MSAs. See Internet Appendix A, Tables A-2 and A-3 for details on the factors utilized in model estimation. 
Figure 2

Contributions to MSA Housing Return Integration Trends

1992:Q2 through 2012:Q4

\section{Panel A: Factor Contributions for 401 US MSAs}

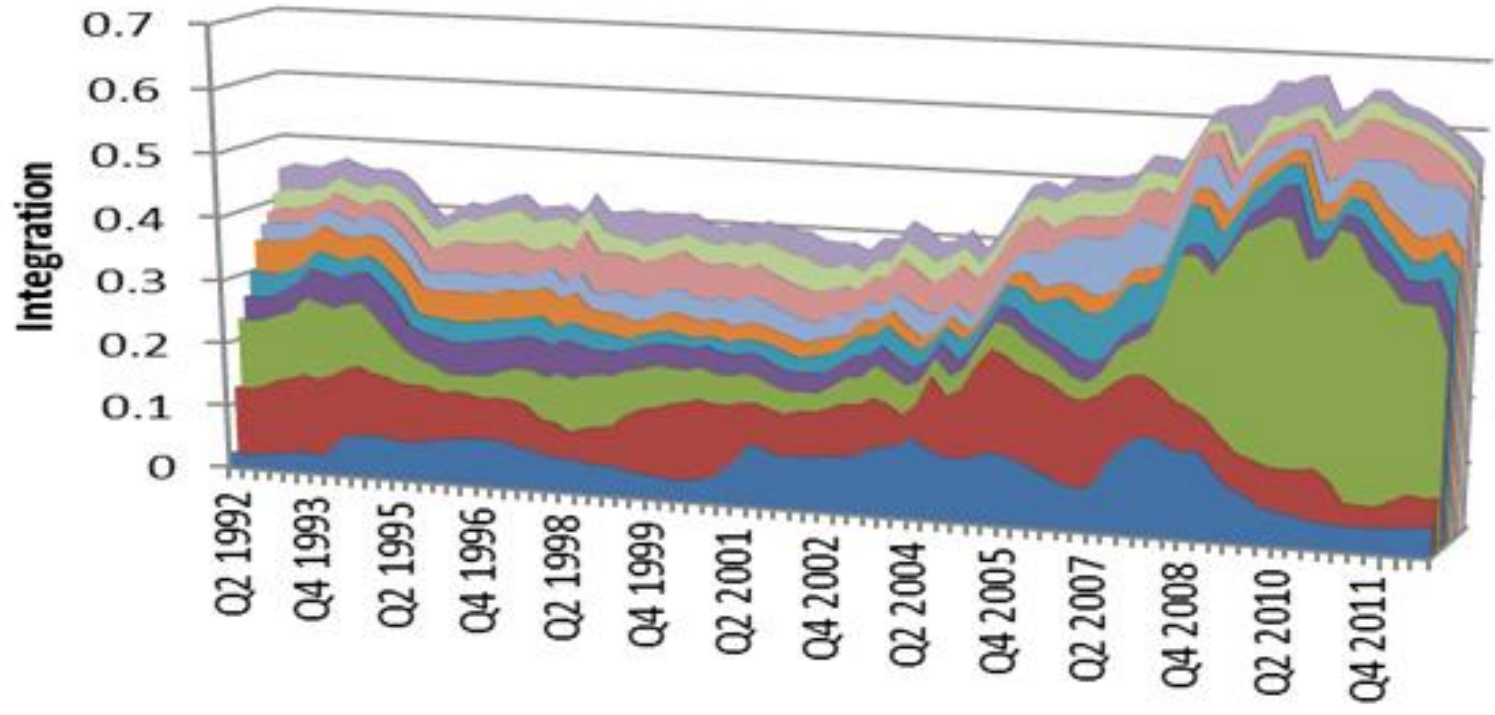

Time

EFEFUNDS 


\section{Panel B: Factor Contribution for 29 California MSAs}

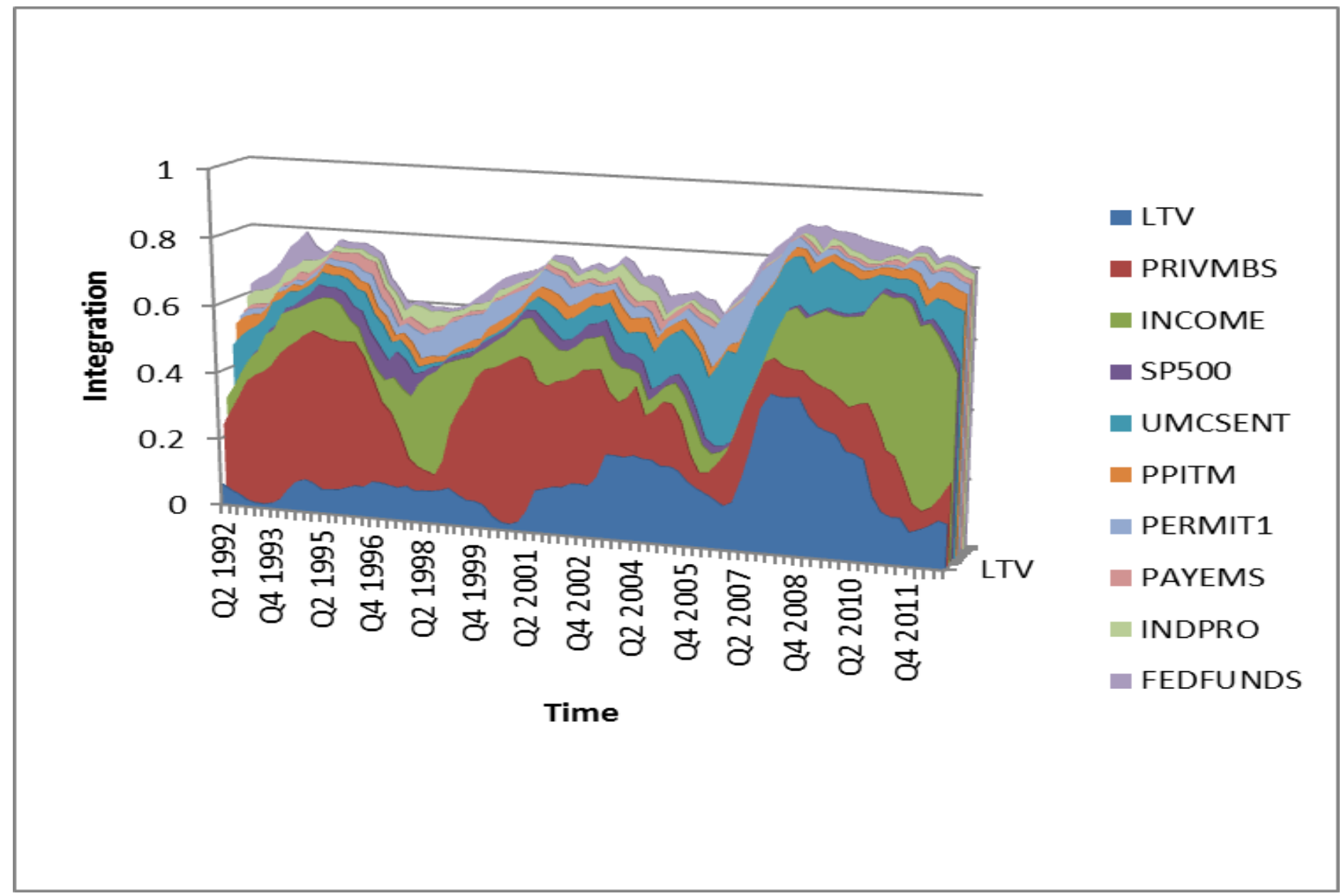

Notes: The level of integration is measured by the R-square from a multi-factor housing returns model estimated for sequential 30quarter moving windows. The R-square contribution of each factor to the level of integration is plotted. Contributions of factors are identified by running a single-factor model and then incrementally adding additional factors and re-estimating the model. The explanatory factors in their order of inclusion are average borrower loan-to-value ratio (LTV), private residential mortgage-backed 
securities issuance (PRIVMBS), personal income (INCOME), equity market returns (S\&P500), consumer sentiment (UMCSENT), PPI materials prices (PPITM), single-family building permits (PERMIT1), payroll employment (PAYEMS), industrial production (INDPRO),and the Federal Funds rate (FEDFUNDS). The incremental R-square is shown for each factor. For example, the plot labelled LTV shows the Rsquare from a single factor LTV model; the plot labelled PRIVMBS shows the R-square from a two-factor model that includes both LTV and PRIVMBS, so the difference in R-square between these models portrays the increment to explanatory power associated with the PRIVMBS factor. The final model, labelled FEDFUNDs, includes all 10 factors up to and including FEDFUNDs. 
Figure 3

Factor Economic Significance and Standard Error Bands

PRIVMBS

-2 Sigma $\longrightarrow$ PRIVMBS $\longrightarrow+2$ Sigma
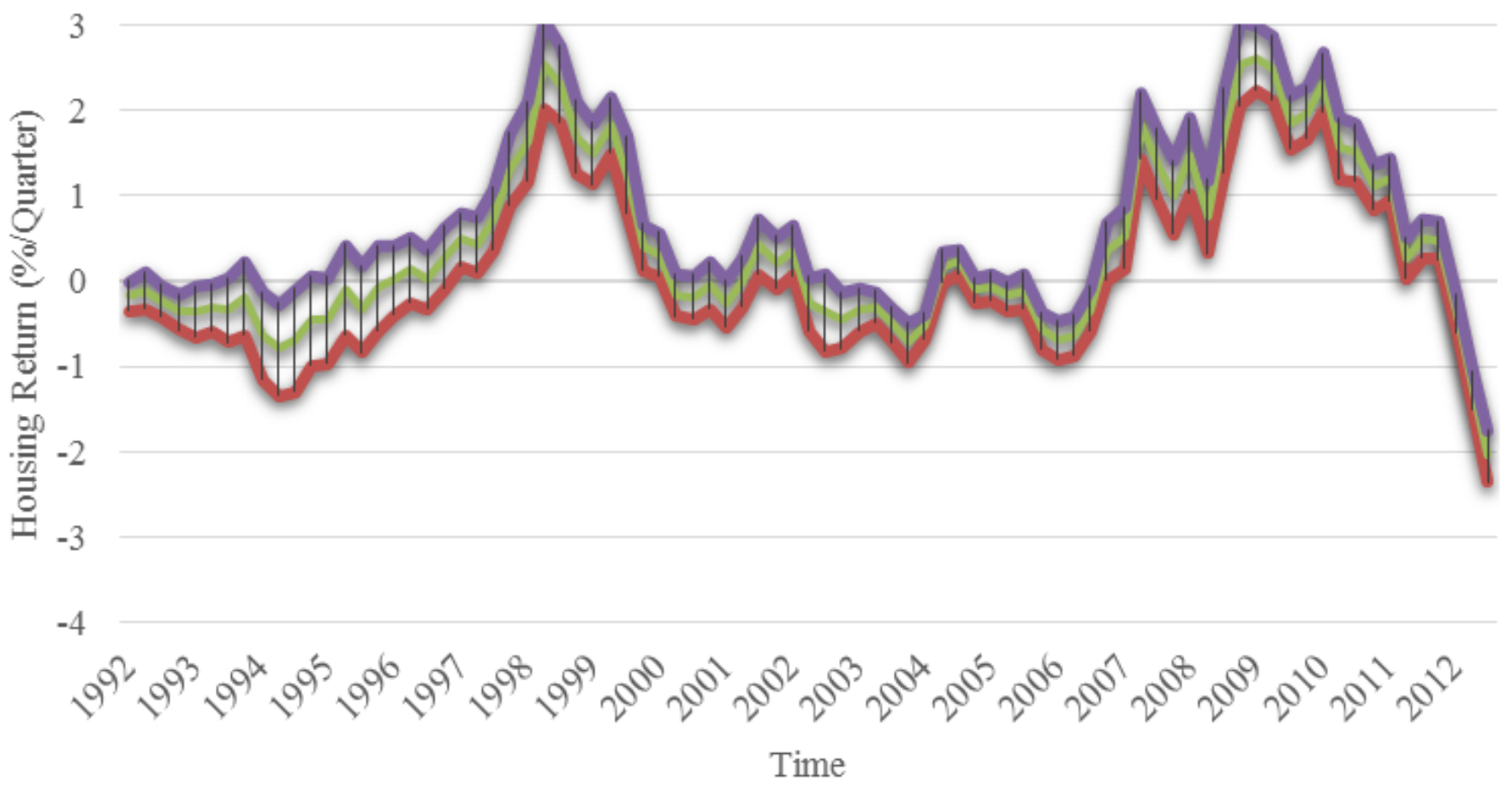

32 


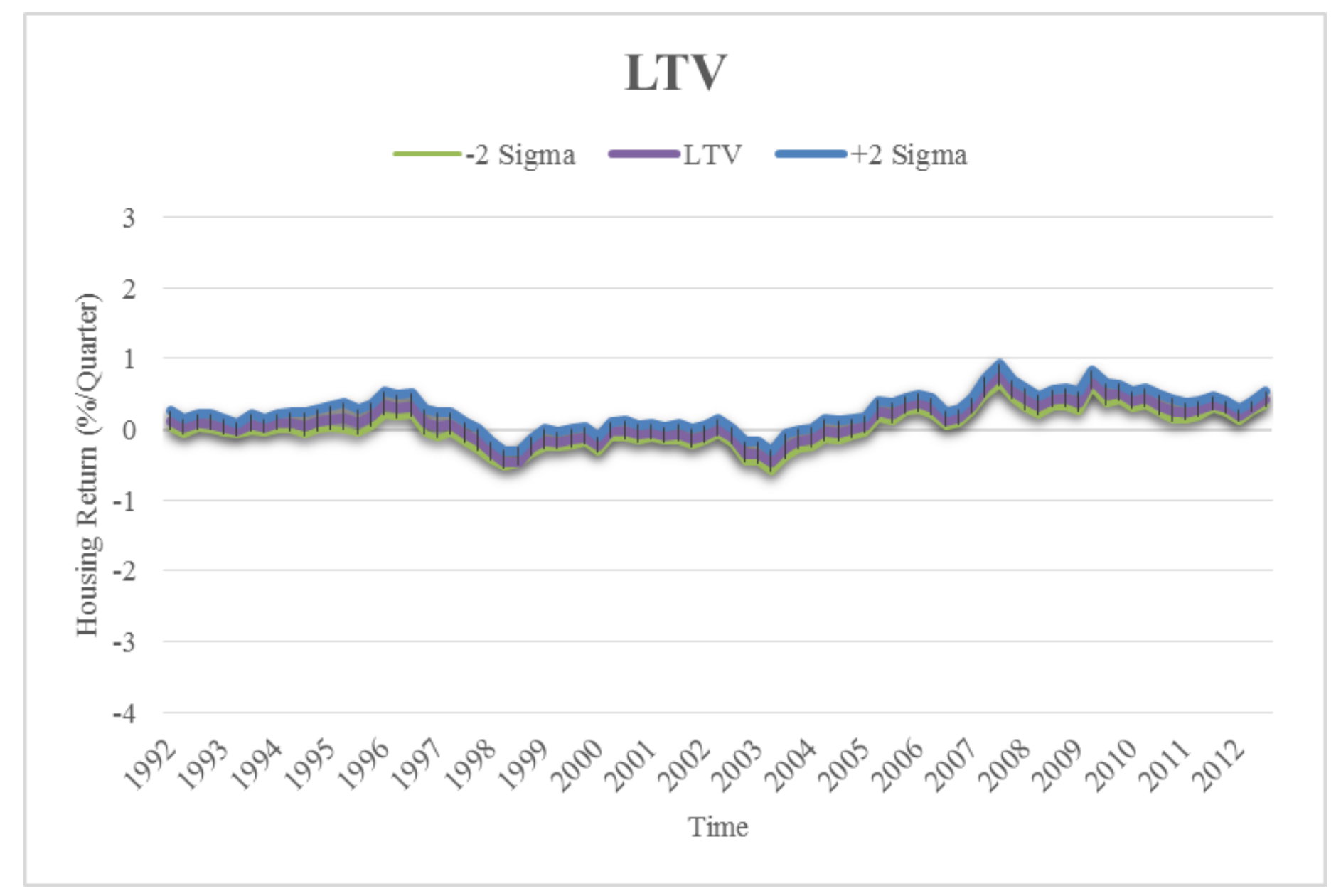

33 
PAYEMS
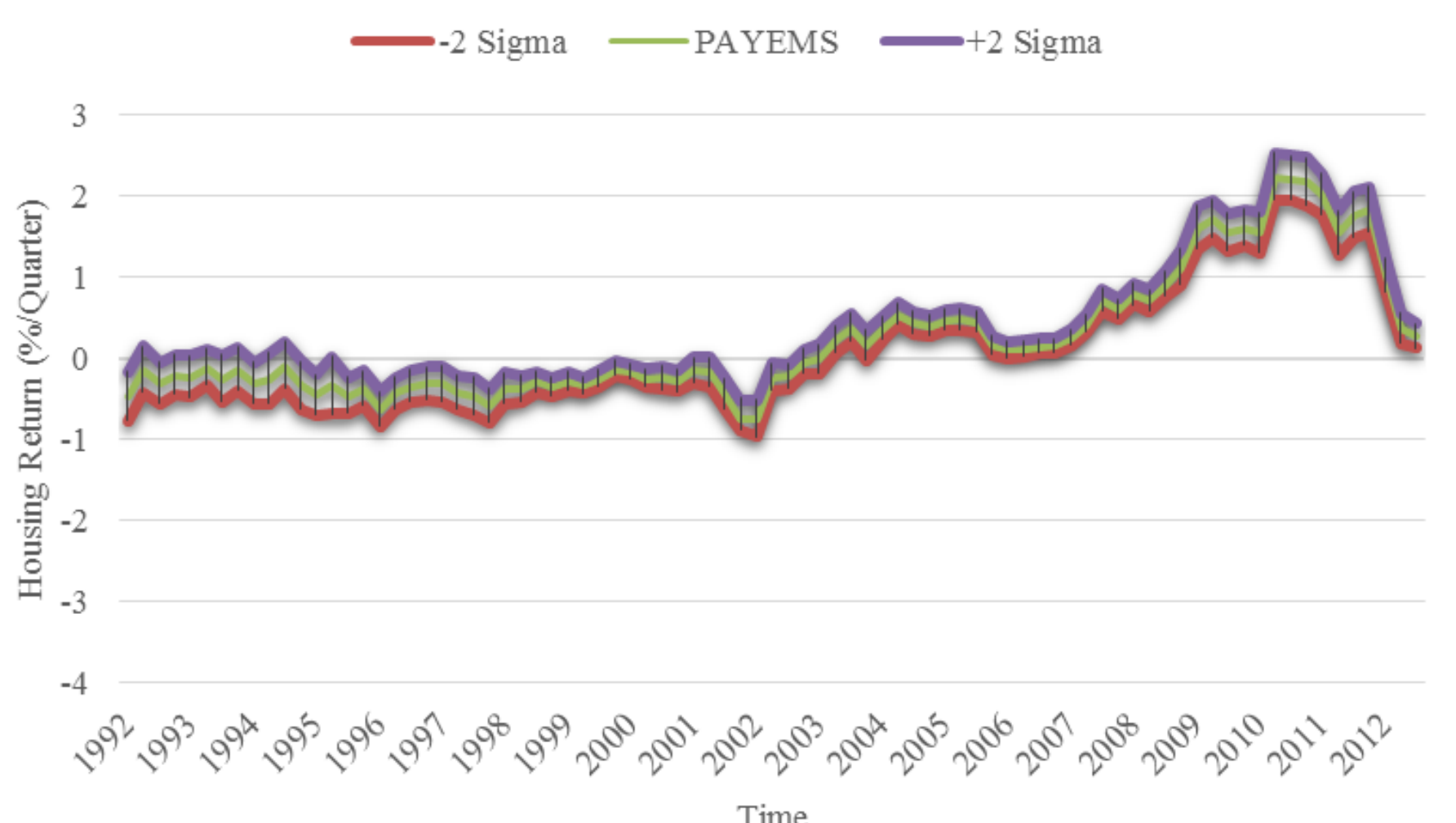

Time

34 


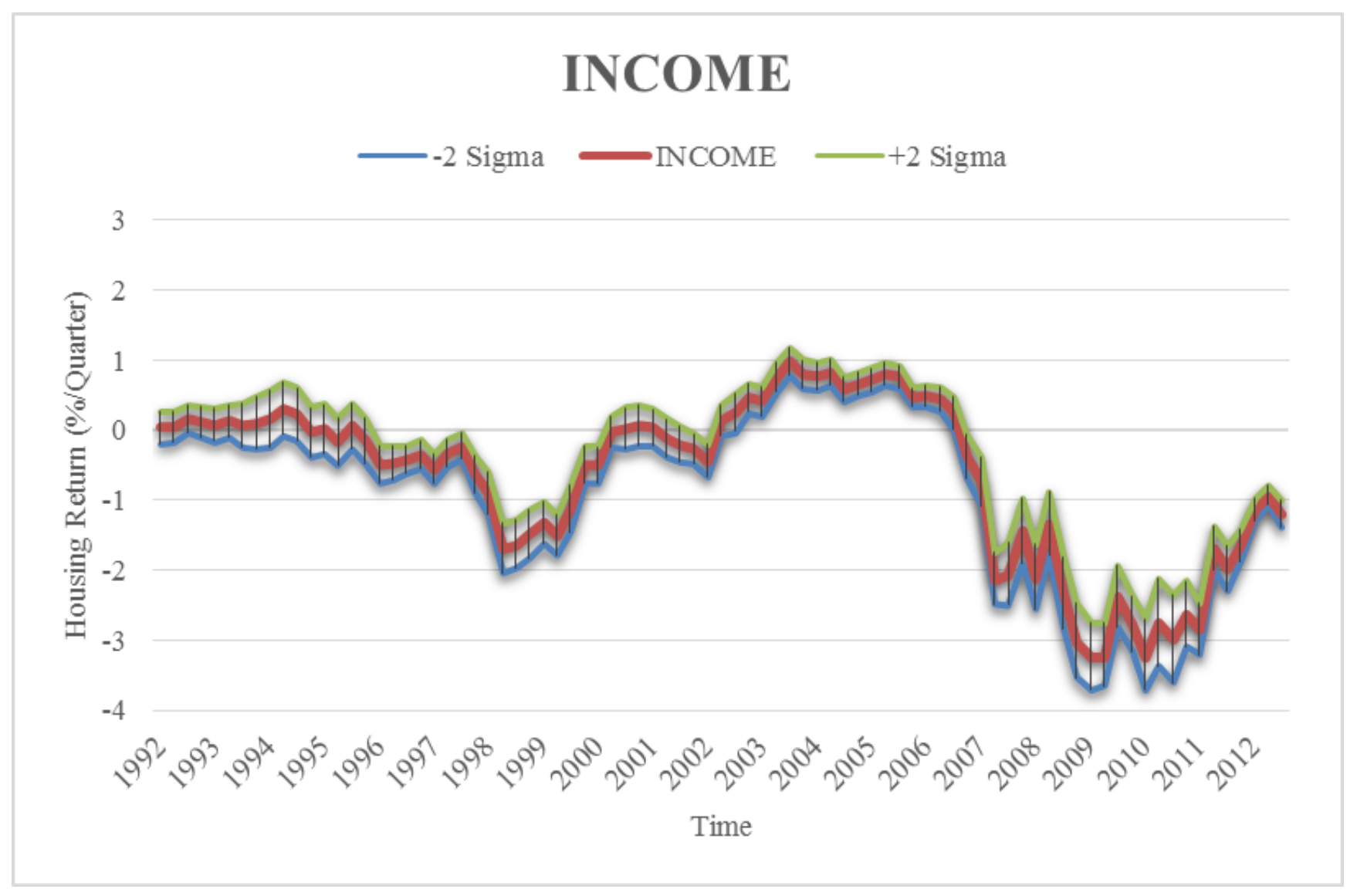

Notes: The economic impact of factors is illustrated using factor bootstrap betas and two sigma standard errors for all 401 US MSAs. The bootstrap - further details in the text - features 500 resamplings of both MSAs and quarters within each 30-quarter window. The economic impact is presented for 1992:Q2 - 2012:Q4 for selected factors from the multi-factor housing returns model fitted using a 30quarter moving window. Four of the most significant factors are depicted. They are private residential mortgage-backed securities issuance (PRIVMBS), average borrower loan-to-value ratio (LTV), payroll employment (PAYEMS), and personal income (INCOME). Similar plots for other factors are available upon request. 


\section{Figure 4}

Housing Return Integration, Portfolio Risk and Diversification Panel A: Integration and Diversification for US MSAs

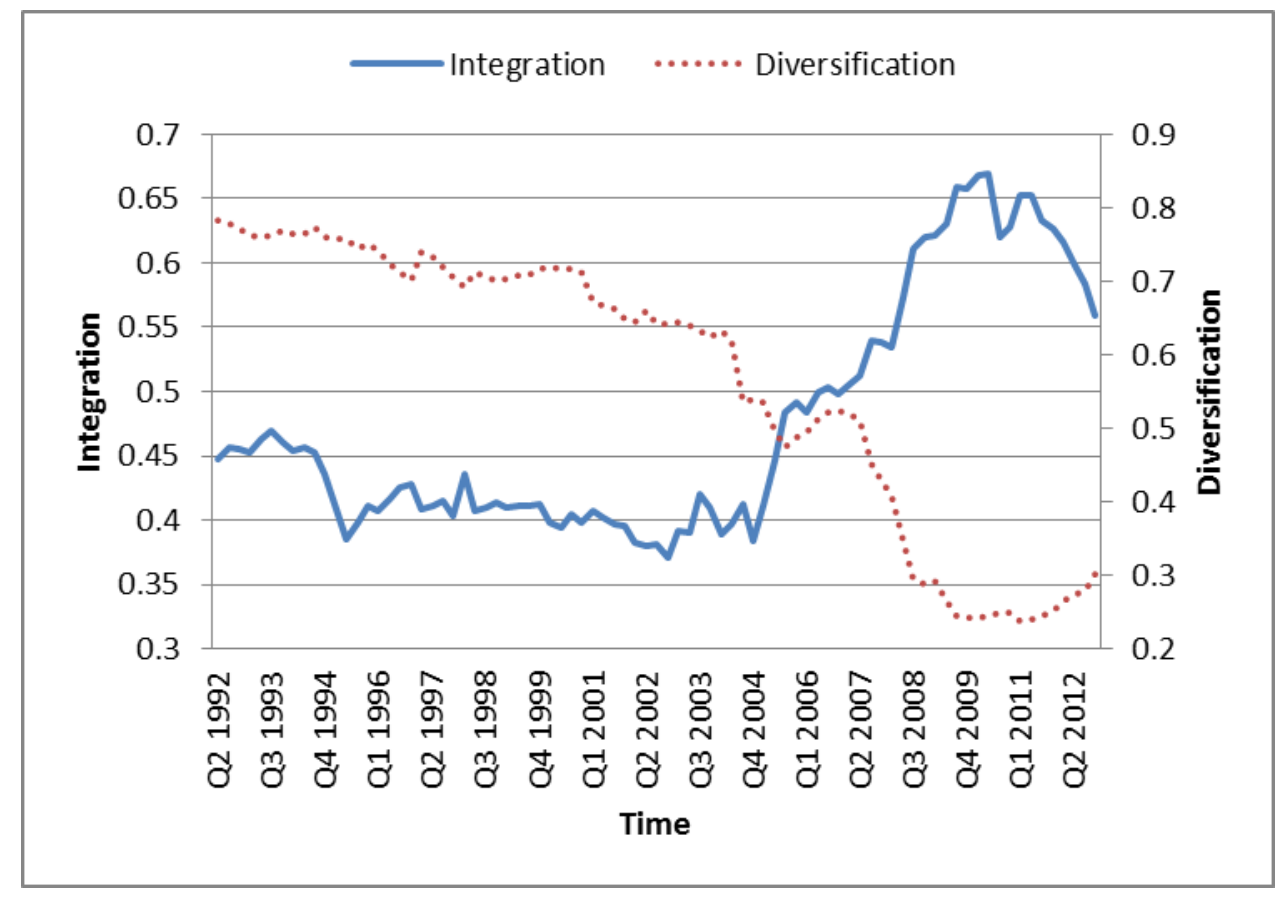




\section{Panel B: Integration and Diversification for California MSAs}

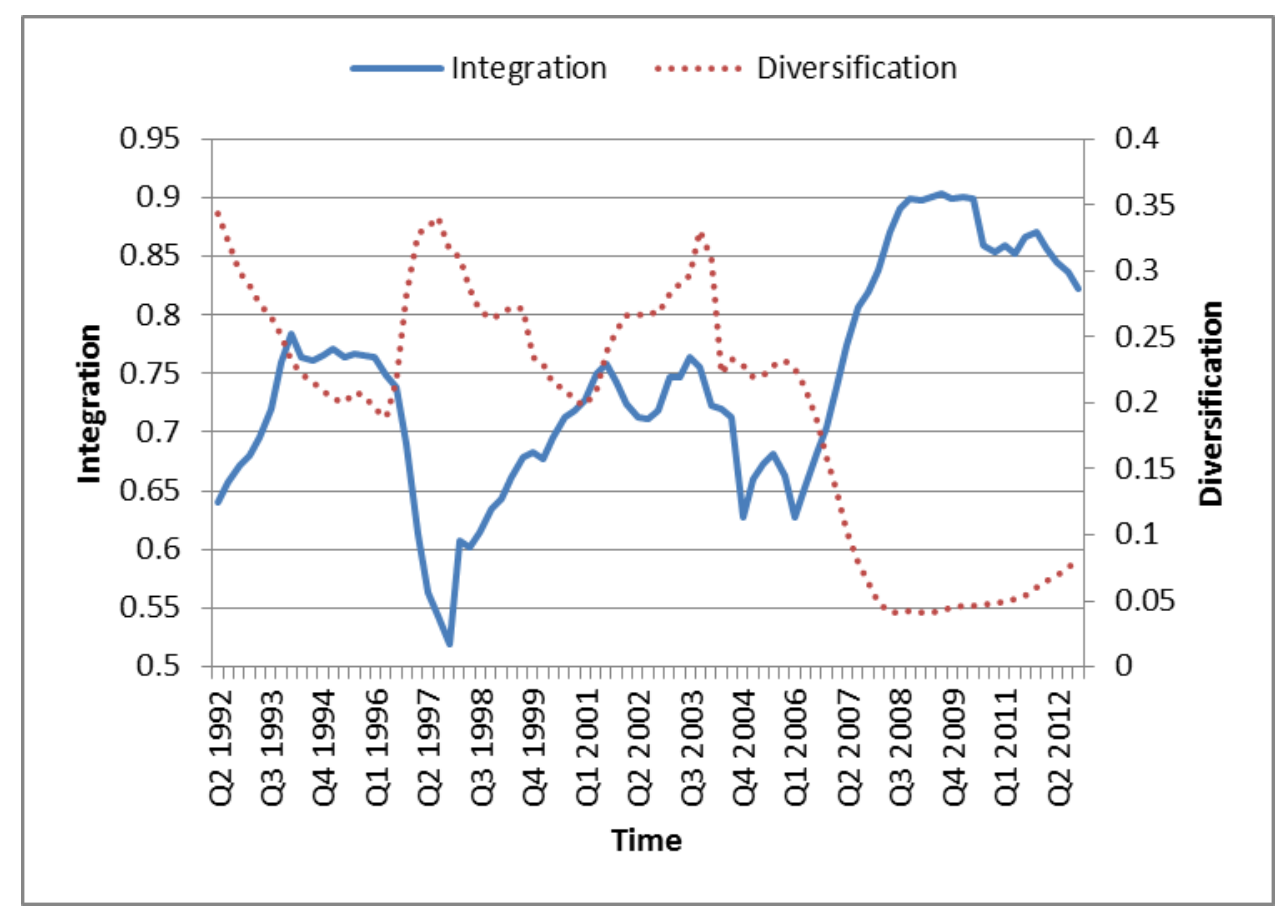

Notes: Integration is measured by the R-squares from the multi-factor housing returns model fit for a sequence of 30-quarter moving windows. Risk is measured by the standard deviation (volatility) of housing returns. Diversification is the average volatility of individual MSAs within an equal-weighted portfolio less the portfolio's volatility. The 30-quarter windows end on 1992:Q2 through 2012:Q4 for 401 US MSAs (Panel A) and for 29 California MSAs (Panel B). 


\section{Table 1}

\section{Contemporaneous and Lagged MSA House Return Correlations by Geographic Cohort, 1985-2012}

\begin{tabular}{|c|c|c|c|c|c|c|c|c|}
\hline & \multicolumn{4}{|c|}{ Contemporaneous correlations } & \multicolumn{4}{|c|}{ Lagged/Leading (one quarter) correlations } \\
\hline & $\mathbf{N}$ & $\begin{array}{l}\text { Number } \\
\text { Significant }\end{array}$ & $\begin{array}{l}\text { Percentage } \\
\text { Significant }\end{array}$ & $\begin{array}{c}\text { Mean } \\
\text { Correlation } \\
\end{array}$ & $\mathbf{N}$ & $\begin{array}{c}\text { Number } \\
\text { Significant }\end{array}$ & $\begin{array}{l}\text { Percentage } \\
\text { Significant }\end{array}$ & $\begin{array}{c}\text { Mean } \\
\text { Correlation }\end{array}$ \\
\hline Pacific & 276 & 118 & 42.754 & 0.437 & 576 & 168 & 29.167 & 0.355 \\
\hline Mountain & 630 & 197 & 31.270 & 0.412 & 1296 & 186 & 14.352 & 0.306 \\
\hline $\begin{array}{l}\text { West North } \\
\text { Central }\end{array}$ & 528 & 41 & 7.765 & 0.272 & 1089 & 11 & 1.010 & 0.143 \\
\hline $\begin{array}{l}\text { West South } \\
\text { Central }\end{array}$ & 946 & 56 & 5.920 & 0.220 & 1936 & 7 & 0.362 & 0.113 \\
\hline $\begin{array}{l}\text { East North } \\
\text { Central }\end{array}$ & 1953 & 561 & 28.725 & 0.393 & 3969 & 205 & 5.165 & 0.236 \\
\hline $\begin{array}{l}\text { East South } \\
\text { Central }\end{array}$ & 2850 & 601 & 21.088 & 0.377 & 5776 & 493 & 8.535 & 0.260 \\
\hline South Atlantic & 780 & 145 & 18.590 & 0.337 & 1600 & 117 & 7.312 & 0.226 \\
\hline $\begin{array}{l}\text { Middle } \\
\text { Atlantic }\end{array}$ & 741 & 236 & 31.849 & 0.386 & 1521 & 240 & 15.779 & 0.273 \\
\hline New England & 136 & 107 & 78.676 & 0.689 & 289 & 191 & 66.090 & 0.552 \\
\hline $\mathrm{CA}$ & 406 & 398 & 98.030 & 0.770 & 841 & 785 & 93.341 & 0.669 \\
\hline
\end{tabular}

Notes: Return correlations are given for contemporaneous quarters and lagged by one quarter broken out by US Census Divisions. $\mathrm{N}$ is the total number of pair-wise correlation coefficients; for example, there are 24 cities (MSAs) in the Pacific Division, so there are $24(23) / 2=276$ distinct contemporaneous correlations and $24(24)=576$ lagged correlations (since each member of a pair can either lead or lag.) The number and proportion of significant correlations with a t-statistic greater than five and the mean correlation are reported. The sample period is from 1985 to 2012 inclusive. Some MSAs entered the data set after 1985 so that their correlations are computed with fewer than the maximum number of observations (112). The t-statistics are based the number of observations available in each case. Geographic regions conform to the nine US census divisions except that California is reported separately (CA). US states in the nine census divisions are: Pacific (AK HI OR WA), Mountain (AZ CO ID MT NM NV UT WY), West North Central (IA KS MN MO ND NE SD), West South Central (AR LA OK TX), East North Central (IL IN MI OH WI), East South Central (AL KY MS TN), South Atlantic (DC DE FL GA MD NC SC VA WV), Middle Atlantic (NJ NY PA) and New England (CT MA ME NH RI VT). 
Table 2

Housing Returns and Integration Measures, 1985-2012

\begin{tabular}{|c|c|c|c|c|c|c|c|c|c|}
\hline Statistic & $\begin{array}{l}\text { Quarterly } \\
\text { Return }\end{array}$ & $\begin{array}{l}\text { Sigma of } \\
\text { Quarterly } \\
\text { Return }\end{array}$ & $\begin{array}{l}\text { First R- } \\
\text { Square }\end{array}$ & $\begin{array}{l}\text { Last R- } \\
\text { Square }\end{array}$ & $\begin{array}{c}\text { Change } \\
\text { in R- } \\
\text { Square } \\
\text { (Last- } \\
\text { First) }\end{array}$ & $\begin{array}{c}\text { Trend t- } \\
\text { stat } \\
\text { (Last- } \\
\text { First) }\end{array}$ & $\begin{array}{c}\text { R- } \\
\text { Square } \\
(2000)\end{array}$ & $\begin{array}{c}\text { Change } \\
\text { R- } \\
\text { Square } \\
\text { (2000- } \\
2012)\end{array}$ & $\begin{array}{l}\text { Trend t- } \\
\text { stat }(2000- \\
2012)\end{array}$ \\
\hline \multicolumn{10}{|c|}{ Panel A. All 401 U.S. Metropolitan Statistical Areas } \\
\hline Mean & 0.794 & 2.088 & 0.448 & 0.559 & 0.192 & 6.5486 & 0.398 & 0.173 & 7.0678 \\
\hline Sigma & 0.198 & 0.743 & 0.219 & 0.212 & 0.235 & 6.1572 & 0.193 & 0.220 & 5.8712 \\
\hline Minimum & 0.165 & 0.816 & 0.071 & 0.112 & -0.390 & -9.0282 & 0.089 & -0.404 & -9.7221 \\
\hline Quintile 1 & 0.532 & 1.169 & 0.178 & 0.254 & -0.154 & -1.6046 & 0.173 & -0.131 & -1.3331 \\
\hline Quintile 2 & 0.681 & 1.617 & 0.307 & 0.424 & 0.075 & 3.1482 & 0.268 & 0.043 & 4.1224 \\
\hline Quintile 3 & 0.768 & 2.022 & 0.405 & 0.567 & 0.197 & 6.1259 & 0.361 & 0.165 & 7.1204 \\
\hline Quintile 4 & 0.888 & 2.428 & 0.561 & 0.712 & 0.327 & 9.2816 & 0.481 & 0.296 & 10.0671 \\
\hline Quintile 5 & 1.098 & 3.246 & 0.788 & 0.840 & 0.517 & 15.9634 & 0.707 & 0.490 & 15.6539 \\
\hline Maximum & 1.412 & 5.326 & 0.966 & 0.920 & 0.679 & 30.6598 & 0.925 & 0.662 & 32.3618 \\
\hline \multicolumn{10}{|c|}{ Panel B. 29 California Metropolitan Statistical Areas } \\
\hline Mean & 0.920 & 3.051 & 0.631 & 0.819 & 0.200 & 5.042 & 0.668 & 0.151 & 4.588 \\
\hline Sigma & 0.272 & 0.490 & 0.160 & 0.081 & 0.141 & 4.686 & 0.237 & 0.211 & 4.987 \\
\hline Minimum & 0.486 & 2.404 & 0.320 & 0.629 & -0.012 & -1.026 & 0.162 & -0.197 & -2.931 \\
\hline Maximum & 1.417 & 4.454 & 0.843 & 0.917 & 0.453 & 14.787 & 0.925 & 0.573 & 13.924 \\
\hline
\end{tabular}

Notes: The columns contain different variables and the rows provide the summary statistic for each column variable. Housing returns for each metropolitan statistical area (MSA) in the sample are the log quarterly differences in its FHFA repeat home sales price index. Sigma is the standard deviation. The R-Square from a multi-factor model is the measure of integration for an MSA. The time trend t-statistics are estimated by regressing the R-squares for each MSA on a simple linear time trend for all available quarters of data and then averaging across MSAs. Both the R-Square for the first 30-quarter estimation window and the R-Square for the start of 2000 are used to depict the trend in integration. The final average R-square is for 2012:Q4 and includes all 401 US MSAs in Panel A and 29 California MSAs in Panel B. The change in R-squares (Last-First) refers to the average difference between estimates for 2012:Q4 and 1992:Q2. The change in R-squares (20002012) refers to the average difference between estimates for 2012:Q4 and 1999:Q4. The crosssectional summary statistics include the mean, standard deviation, minimum, the mean values of quintile 1-5 (in Panel A), and the maximum for the variable in each column. 


\section{Table 3}

\section{Correlations between Integration and Diversification for Different Periods}

\begin{tabular}{|ccc|}
\hline Time & Entire US & California \\
\hline Full Sample & -0.899 & -0.862 \\
The 2000s & -0.966 & -0.836 \\
Boom & -0.775 & -0.738 \\
Bust and Aftermath & -0.862 & -0.758 \\
\hline
\end{tabular}

Notes: Correlations between integration and diversification are presented for the U.S. and California over four time periods. Integration is measured by the average R-square from our multi-factor housing returns model fit to a sequence of 30-quarter moving windows. Diversification is the average volatility of individual MSAs within an equal-weighted portfolio less the portfolio's volatility. The Full Sample has 30-quarter windows ending from 1992:Q2 to 2012:Q4. The 2000's are from 2000:Q1 to 2012:Q4. The Boom is from 2004:Q1 to 2007:Q4. The Bust and Aftermath is from 2008:Q1 to 2012:Q4. 